\title{
GEORGE ORWELL'S NINETEEN EIGHTY-FOUR: HOW A UTOPIA TURNED OUT TO BE A DYSTOPIA
}

\author{
Rana Erdoğan ${ }^{1}$
}

\begin{abstract}
As a literary period, modernism indicated the birth of the new ideas and approaches to art. This period from a political aspect also marked the beginning of the expansion of socialism; for this reason, the literature portrayed the division between the ideas of right- and left-winged intellectuals and how they visualised their ultimate utopias which were based on the political ideas they supported. In time, because of the idealistic approaches of the writers to the issues around them, their realities became a subjective reflection of their political beliefs since their works were highly influenced by them and eventually they started to produce the propaganda of their political views in their literary works. With Nineteen Eighty-Four, George Orwell aims to portray his fears about the future by creating a society in which the external reality is controlled by the authority. In the novel, Orwell reflects the fragmented mind of the modern people through the conflict between his protagonist Winston, who wants to protect the last traces of his humanity, and the Party members that aim to reduce humanity into hollow beings by producing their version of the actuality. As a modernist writer, within the novel, Orwell both experiments with new forms and subject matters with the way he illustrates the psychological effects of constant warfare and criticises the people who have the power in his society for focusing on the control they have over the majority instead of encouraging enlightenment for he believed that their utopia originated a dystopia.
\end{abstract}

Keywords: George Orwell, Nineteen Eighty-Four, Modernism, Dystopia.

\section{GEORGE ORWELL'IN 1984 ROMANI: BİR ÜTOPYANIN DİSTOPYA İLE SONUÇLANMASI}

$\ddot{O} \mathbf{z}$

Edebi bir dönem olan modernizm sanata karşı yeni yaklaşımların ve fikirlerin doğumu olarak kabul edilmektedir. Aynı zamanda bu dönem politik açıdan sosyalizmin geniş kitlelere yayılmasının da başlangıcına denk gelmektedir. Bu yüzden de bu edebi akım sağ ve sol görüşlü yazarların yaklaşımları arasındaki farklılıkları ve siyasi görüşlerine dayanan nihai ütopyalarını nasıl resmettiklerini betimlemektedir. Zaman içinde yazarların, onları çevreleyen sorunlara olan idealistlik yaklaşımlarından ötürü ortaya koydukları edebi eserlerindeki gerçeklikleri de etkisinde oldukları siyasi görüşün öznel bir yansıması olmaya başlamasıyla, en sonunda edebi eserlerini siyasi görüşlerin birer propagandasına dönüştürdüler. 1984 eseriyle George Orwell, toplumda güç sahibi olanların kontrol ettiği bir evren yaratarak insanlığın yarınını göstermektedir. Bu romanda Orwell, insanlığının son kırıntılarını korumak isteyen Winston ve insanlığı kendi gerçekliklerini üreterek yok etmeyi hedefleyen Parti üyeleri arasındaki çatışmayla birlikte modern insanların parçalara ayrılmış zihnini yansıtmaktadır. Modernist bir yazar olarak, roman içerisinde Orwell bitmek bilmeyen bir savaşın psikolojik etkilerini tasvir etme şekliyle hem yeni biçimler hem de yeni konulara değinmekte ve de toplumun üst sınıfını aydınlamayı teşvik etme yerine diğerleri üzerindeki kontrollerine odaklanmayı seçtikleri için eleştirmektedir çünkü ona göre onların ütopyaları bir distopya ile sonuçlandı.

Anahtar Kelimeler: George Orwell, 1984, Modernizm, Distopya.

Modernism can be regarded as one of the richest literary periods. During this period, thanks to the rapid technological developments, the writers were in continuous touch with the other countries, their literature and politics. Due to these reasons, in time, there was an undeniable Russian influence in British literature and politics, especially under the political aspects of this influence, some writers became the defenders of the new egalitarian understandings of Russia while some believed that it was doom to fail. Although in the literary aspect, writers like Virginia Woolf and T. S. Eliot openly stated their admiration for the Russian art, especially Woolf in her essay titled as 'The Russian Point of

\footnotetext{
${ }^{1}$ M.A in English Language and Literature, Kocaeli University, rn-erdogan@ hotmail.com, https://orcid.org/00000001-5196-5150.
} 
View' mentions her admiration for the Russian literature with these words: "we have judged a whole literature stripped of its style" and while talking about Anton Chekhov, she adds that "as we read these little stories about nothing at all, the horizon widens; the soul gains an astonishing sense of freedom" She also comments on the lack of the central plot in the stories and how they allow the reader to explore the mentality of the characters. Other than this, while talking about Dostoyevsky and Tolstoy, she stresses on their ability to reflect the inner world of their characters and calls it in general as 'Russian point of view', which can be associated with the stream of consciousness technique that the modern writers aimed to explore. However, with the Bolshevik Revolution in 1917, the Russian literature took a different turn (Taunton).

In 1945, the Second World War officially ended but the Russian Soviet Federative Socialist Republic and its ideas brought a new threat. In 1946, the Cold War between Soviet Russia and the USA began. The Russian idealism for some was the ultimate utopia; nevertheless, some thought that it was the ultimate dystopia and for these reasons, both sides began to form a new type of literature which is based on positive and negative propagandas about socialism. Fredric Jameson states that "During the Cold War, utopia had come to designate a program which [...] betrayed a will to uniformity and the ideal purity of a perfect system that had to be imposed by force on its imperfect and reluctant subjects." (qtd in Hammond 664-665) and as Jameson explicitly claims, unlike utopia, dystopia started to emerge and with the beginning of the mass arrests, show trials, political terror and the suppression of writers in Russia, the socialism became a real-world dystopia in time. While socialism did find the perfect place to be practised in Russia with the rise of Soviet Union and eventually came to be known as a practice which did not become the reflection of the utopia that they desired to project after the Second World War, nevertheless, the idea was not only regarded as a desirable pursuit in Russia at the beginning. In 1884, Fabian Society, a foundation which is strongly connected with the Labour Party and socialism, was founded in London. This foundation with its famous members such as George Bernard Shaw, Graham Wallas and Sidney Webb rejected the revolutionary side of Karl Marx's theories and claimed that socialism was inevitable; however, they believed that instead of a revolution, it would occur as a gradual transition. These Fabians aimed to make people believe in their ideas through the use of propaganda, which they called 'permeation'. In 1930, Webb openly began to support Soviet communism and Shaw expressed his admiration for Benito Mussolini, Italy's fascist dictator and in 1931, George Douglas Howard Cole formed the New Fabian Research Bureau, which included names such as Leonard Woolf, William Robson, Hugh Dalton, and Evan Durbin (Lamb). George Orwell, while he was known for his support to socialism, was against the Fabian Society and its ideas, for he believed that such movements had immense potential for dictatorship. During the Second World War, Orwell was working for the Ministry of Information and BBC, where he witnessed the totalitarian roots of the ideas of left intellectuals, he especially despised how Fabian intellectuals believed that their education gave them a higher status in society and made them 'high-born', and other than this he also witnessed the Machiavellian turn in their ideas and their desire to conquer the whole world (Goodman 34). In Nineteen Eighty-Four (1949), Orwell depicts his disillusionment about how the Bolshevik Revolution and the Fabian Society turned out to be the selfish and cold-hearted by transforming them into inhuman Inner Party members because in the end, for him, socialism was a utopia that turned out to be a dystopia. As it can be understood by the fact that at the beginning with the socialism idea some societies, such as Russian society, aimed to create the perfect society; however, the society they created became the utopia of the people who have the authority and the dystopia of the people who lacked this power.

In both Animal Farm (1945) and Nineteen Eighty-Four, Orwell explores potential abuse of power that could occur in the governmental systems and strongly criticises the rise of the new type of people who abuse their power in the socialist regimes. According to Robert Dahl, there are three faces of power: in the first face group, A has power over group B and A can force B to do something that they do not want to do. In the second face group B is so powerless that the first group holds the whole power and also prevents group B being involved with the first group. The third face is the most dangerous one because in this face the first group can convince the second group to believe or desire what they want them to do. Orwell experienced the second face of power in Spain, during the Spanish Civil War in 1936 - 1939. At that time Orwell participated in the war as a supporter of Partido Obrero de Unificacion Marxista and there he witnessed the cruelty of the communist revolutionaries that were 
supported by Soviet Russia since P.O.U.M. members refused to bow down to these communists they were killed by them and Orwell barely managed to escape to France (Crothers 395-397). The events, he witnessed during this war and later at the $\mathrm{BBC}$ with the Fabians played a very important role in the creation of the Inner Party members of Nineteen Eighty-Four and how they shaped the reality according to their desires. As he states;

\begin{abstract}
Sometimes I look at a Socialist, - intellectual, tract-writing type of Socialist- and wonder what the devil his motive really is. The underlying motive of many Socialists I believe, is simple a hypertrophied sense of order. The present state of affairs offends them not because it causes misery, still less because it makes freedom impossible, but because it is untidy; what they desire, basically is to reduce the world to something resembling a chess-board. (397)
\end{abstract}

In Nineteen Eighty-Four, Orwell designs a world in which a privileged part of the population creates a world order according to their wishes. His Oceania, the name of one of three superpowers that control the Earth and the main focus of the novel, is the third face of power. In the novel, in order to protect their position, Inner Party members reshape the reality and by changing it, they control the reality of the world. In the Modern Period, the writers through the use of fragmentations rejected the linearity of time and objectivity of information. In these claims, newly discussed psychological theories played an important role, during this period, the writers were under the influence of these theories; therefore; they believed that the external reality was a subjective matter and every individual originates their own versions of the reality. For this reason, while producing their works, they paid attention to these notions. For example, they rejected the linearity of time because according to them, subjective reality replaced the objective reality and as a result of this, every individual perceived the time notion in a different manner and to demonstrate is fact they relied on fragmentations (Greenblatt 1839). As one can see in the Modern period, psychology and the rejection of objective reality had a strong connection with each other and Orwell, with his Oceania, demonstrates how the external reality is reshaped by the internal reality. Orwell in both Spain and England witnessed how the communists and British government altered the reality by preaching their propagandas according their wishes and as a consequence of this, it can be claimed that he did not trust both of them. In Nineteen Eighty-Four, in order to criticise them, he created a socialist government and demonstrated that they behave according to their own benefits. It can be stated that with this fictional socialist government, Orwell wanted to demonstrate the corruption in his actual society for he believed that the people who were in power, during his time, misused their power to advance their positions just as in the case of Soviet Russia.

Since Orwell aimed to illustrate how changeable the reality was and how it was changed with the use of propaganda, in the novel, the external reality and the internal reality of the people constantly change according to the desires of the Party. In the totalitarian government of Oceania, everything can be transformed into reality through the use of 'doublethink' a practice that "Even to understand the word 'doublethink' involved the use of doublethink." (Orwell 38). Doublethink exists due to the Inner Party's desire to control the Outer Party members. As one of the party slogans says "Who controls the past, controls the future: who controls the present controls the past." (37), the power of the party is based on the use of doublethink, through this practice, the party is able to alter the reality and create an omniscient subject, Big Brother. In the Ministry of Truth, Recording Department is responsible for the alteration of past; every day in the novel, the main character Winston Smith and many people like him change the past documents in order to protect the power of the Party. While doing their jobs, these people come across many dangerous pieces of information and with the help of memory holes they erase the existence of those pieces, but since the Party refuses the existence of them in the first place by practising the doublethink technique, the individual is forced to refuse the existence of any information which is in a contradiction with the reality of the Party. For them, if Party says black is white, then black is white:

The keyword here is blackwhite. Like so many Newspeak words, this word has two mutually contradictory meanings. Applied to an opponent, it means the habit of impudently claiming that black is white, in contradiction of the plain facts. Applied to a Party member, it means a loyal willingness to say that black is white when Party discipline demands this. But it means also the ability to believe that black is white, and more, to know that black is white, and to forget that one has ever believed the 
contrary. This demands a continuous alteration of the past, made possible by the system of thought which really embraces all the rest, and which is known in Newspeak as doublethink. (221)

Alteration of the past does not mean the alteration of memory; therefore, the Party has to make people believe into the rightfulness of the information they prove, but as one of the Party slogans demands "Ignorance is strength" and in the novel, the ignorant position of Outer Party members and the proles gives the Party the necessary strength to control them. By erasing and re-writing the past, the Party destroys the knowledge and since this process is known by the other party members at some point all the knowledge - and reality - loses its stability and at that point, in order to protect their sanity an individual has to practice doublethink.

As it is mentioned previously while the Party could alter the reality and knowledge, it cannot alter one's memory and for this reason, according to Winston, proles, a group that consists of 85 per cent of the population, are the only ones who are capable of making a change since they still hold on the traditions, and most importantly they remember what it is to be a human (Phillips 72). The desire to be a human and remember the past again becomes the downfall of Winston in the novel for eleven years before the beginning of the novel, Winston finds a photograph and thanks to that photograph and his memory, he finds a piece of information that contradicts with the reality of the Party and at that moment he destroys that information but later his refusal to practise doublethink forces him to question the reality which is created by the Party as he states that he understands how but does not understand why (Orwell 79-81). With this example, one can observe that the lesser party members are aware of the fact the reality is constantly altered by the Inner Party members and Inner Party members since they know that their control over the others is very fragile, changes the past to create an obedient society which believes the truthfulness of every information the Party provide them. In the end, he claims that "Freedom is the freedom to say that two plus two make four. If that is granted, all else follows." (84) and in the novel, the subjective reality of the Party replaces the objective reality and therefore, Winston throughout the novel seeks 'the truth' and as a member of the Party, he is forbidden to reach the objective truth and for that reason, he has to be punished and for this reason, torture comes to the front as a way to protect the external reality which is produced by the Inner Party members.

Torture was abolished in Naples in 1738, England in 1762, Austria in 1776 and France in 1780 since it was regarded as a crime against humanity and it was also regarded as useless practice since a person in order to get rid of the pain was ready to confess even the crimes that he or she did not commit. Until the Second World War, it stayed that way, but during the war, this practice changed and even the civilians were considered to be as the war casualties and later they named those causalities through the use of an Orwellian doublethink as 'enemy combatants'; they were accepted as neither a combatant nor civilian but as someone, if the situation requires, it can be killed (Castresana 119-126). From this aspect, Winston is an enemy combatant, he does not directly involve with the enemy but his hatred towards Big Brother and Party changes his status as a civilian, and also in here one has to consider the fact that he is only taken into the Ministry of Love after he is supposed to take part in with the Brotherhood. In short, since the ideas of Winston and the truths of the Party are in a contradiction with each other, Winston is a threat; therefore, he has to be eliminated. Orwell with Winston and O'Brien characters shows the destructive effects of fanaticism and lack of critical thinking, both of them, in order to protect their reality, are ready to cross the line between the human and inhuman. Winston hates Big Brother and is ready to do anything to destroy him and what he is ready to do does not make him better than an Inner Party member. For example, O'Brien while pretending to be a member of the Brotherhood asks Winston how far he is willing to go and asks whether he is ready "...to cheat, to forge, to blackmail, to corrupt the minds of children, to distribute habit-forming drugs, to encourage prostitution, to disseminate venereal diseases - to do anything which is likely to cause demoralization and weaken the power of the Party?" (180) or not and Winston simply says 'yes' without any hesitation and later O'Brien performs some of these actions while he tortures Winston for the sake of his and Party's reality. In this part, Orwell proves that the desire of the perfect society, this utopia is always under threat of becoming a dystopia. Considering that in order to originate his version of a utopia, Winston is ready to commit immoral actions, it can be claimed that his utopia is the dystopia of the other people who reject his ideas. Also, in this paragraph, the uncertain 
position of the human in the modern period can be observed since modernists regarded the external reality as a subjective reflection of one's mind, the position of the individual differs from one person to another. For example, while the Inner Party members see Winston as an enemy combatant, to those who share his ideas, he can be considered as a saviour and this proves the modernist belief that reality changes according to one's point of view that can be accepted as correct.

Throughout the novel, it is stated that the only way to bring the Party down is refusing to believe the reality of the Party and for this reason, the biggest crime is the thoughtcrime. In Part III, Chapter I, one can see that only the Party prisoners are treated as a real criminal, because the other criminals, especially the murderers are regarded as people who are doing 'the dirty work' of the Party. Therefore, it can be deduced that the only crime is the thoughtcrime (238-239). The Party coerces people to believe in their reality for two reasons which are to prevent the emergence of new ideologies that threaten their position and to feed the sadistic satisfaction they gain from controlling the minds of the others (Martin 238). As O'Brien says;

The second thing for you to realize is that power is power over human beings. Over the body - but above all, over the mind. Power over matter - external reality, as you would call it - is not important. Already our control over matter is absolute. (Orwell 277)

For that, the only real crime in Oceania is the thoughtcrime. They are able to control the behaviour of the Party members but even with the help of telescreens that always watch every movement, thoughts are something that they cannot control and if the members hide their physical reactions to the events then one can never guess what the others think. Due to the reason that the ideology of the Party is built on the control of the reality and coercing the others to 'believe' it, the Party can never be sure of the loyalty of its members. Since the thoughts are a part of the individual reality through the torture the Inner Party members aim to 'erase' humanity of one. Because of his ideas according to O'Brien, Winston is 'the last man' and O'Brien's mission is to destroy the humanity of the last man.

In this case by erasing the memory of an individual, the Party desire to erase the previous knowledge about their society and what it means to be a human being since they mean to create obedient subjects without any trace of individual thought. George M. Enteen claims that "A loss of memory risks the loss of our entire humanity." (Enteen 214) and O'Brien to destroy the remains of Winston's humanity firstly attacks his memory and claims that he suffers from 'a defective memory' and unable to connect with reality. In one of his writings once Orwell said that schizophrenic individuals have "the power of holding simultaneously two beliefs which cancel out, [the other]" and they ignore "facts which are obvious and unalterable, and which will have to [be] faced sooner or later." (qtd. in Roazen 693) Here ironically not Winston, who is treated as a mentally ill person, but O'Brien, who is the master of doublethink, can be considered to be a borderline schizophrenic. Doublethink is a practice that requires a mental illness and Orwell while explicitly questions the mentality of the high officers of the Party, also questions the objectivity of the reality because as one can see in the novel, Winston represents the minority within the society, but the majority and its socalled objective reality does not have any connection with objectivity. With ' $2+2=5$ ' Orwell proves his readers the fact that objective reality depends on a subjective majority.

In Nineteen Eighty-Four, Orwell other than his critical approach to socialism comes to the front with the deep psychological analyses of his characters and the paranoid universe of Oceania. He depicts the wounds, some psychological problems such approaches cause, especially with the torture scene in the novel which resembles a therapy and with the example of Big Brother that always spies on the Party members. Even in the memories of Winston, one can observe the lack of a fatherly figure, when it is compared to the authorial figures of Big Brother and O'Brien and his constant disobedience to these figures. One can connect this with the Oedipus complex for in the case of the Oedipus complex, the child consistently fears that his father will castrate him in order to prevent the child from taking the authoritarian position of the father. In Freud's one of the most famous cases, Dr Schreber's memoirs, the father desires to make children perfect by using his authorial power over the children and O'Brien as a father figure desires to turn Winston into a perfect citizen by torturing him. In Freud's case, father claims that "the most important thing is that the disobedience should be crushed to the point of regaining complete submission, using corporal punishment if necessary." (Sperber 221-222). 
However, the paranoia of being dethroned by a more powerful figure is mutual in the case of Nineteen Eighty-Four. While Winston is openly afraid of the authority, the Party, which is the embodiment of authority, is also afraid of critical thinking abilities of the Outer Party members. For this reason, they vaporised these people who question their power because their powerful position depends on their ability to alter the reality and due to this reason, they aim to reshape the personality of Winston by psychologically torturing him. The modern writers were keen to use new subject matters and to explore the mentality of their characters. As it can be seen in this example, Orwell, according to some critics, uses psychology to enrich the way he describes the inner worlds of his characters. Also, it can be observed that in this novel, Orwell uses psychology to explain how the Inner Party members reshape the external reality, and why these people are extremely paranoiacs since they are under threat of losing their privileged position in society.

Apart from Oedipus complex and paranoia, Freud's claiming that humans are unconscious beings plays an important role in the novel because Thought Polices are able to catch the ideas of people through their unconscious movements:

The smallest thing could give you away. A nervoustic, an unconscious look of anxiety, a habit of muttering to yourself -anything that carried with it the suggestion of abnormality, of having something to hide. In any case, to wear an improper expression on your face (to look incredulous when a victory was announced, for example) was itself a punishable offence. There was even a word for it in Newspeak: facecrime, it was called. (Orwell 65)

In the quotation above Winston describes the inevitability of body's betraying the mind and its destructive results. Since the ideology of the Party is accepted as the most important thing in life, the Party members have to dedicate their whole lives to the success and continuity of the Party and they consistently have to discipline themselves to think according to benefit of the Party. This is a practice called as crimestop because the Party is the new religion and acting against the teachings of it is a heresy.

In Oceania using the word 'god' or committing yourself into any kind of religion is a crime because there is only one god, Big Brother and the Inner Party members are accepted as his priests that worship the power he provides them. Patricia Hill, in her article, comments on the religious rituals of the Party and expresses that "For Oceania, void of religious belief, has yet all the trappings of a theocracy: a godhead, a high priesthood, and the discipline and ritual of a state religion." (Hill 275). The party even has a devil that it could blame for the war and disorder; and as a religious practice, the Party in every 'Two Minutes Hate' reminds people of their real enemy and it also, along with this practice, creates an environment which allows the Party members to express their emotions (Orwell 13-18). It is the only time when they are allowed to reveal any form of emotion other than their appreciation to Big Brother and for the ones like Winston, it is the only opportunity of voicing their hatred to Big Brother, but since they cannot convey this hatred openly, they externalise it as the hatred of Goldstein. The civilised, perfect people of Oceania are only able to express emotion through such religious rituals like Two Minutes Hate and Hate Week and for them, as it can be seen in the example of Hate Week, the enemy does not matter because the only important thing for them is the limited ability to express an extreme emotion and rejoicing in the comfort follows afterwards. In this part of the novel, it is visible that Orwell criticises the direction the socialism took for his Big Brother and the Party come to the front as a metaphor for Soviet Russian and British politicians that during the Second World War originated their versions of the actuality and through their propaganda forced their societies to believe the rightfulness of their discourse. Due to these reasons, it can be claimed that the Modern writers questioned the truthfulness of reality and wanted to express the feeling of depression which dominated their societies.

By limiting the expression of emotion and giving a godlike status to Big Brother, the Party aims to dehumanise the society until only the 'love' they supposed to have for Big Brother remains. Even the torture of Winston serves to this purpose because the Party has the capacity of eliminating the existence of rebels like Winston but firstly they desire to convert them into the new religion of the Party for otherwise if they fall to convert them then they would lose their ability to control the reality. Due to this reason, the Party through the means of torture before killing Winston physically, they 
murder him in the mental sense and they do this by dehumanising him. As O'Brien claims, the Party already managed to destroy the emotional bonds among the human beings:

\begin{abstract}
The old civilizations claimed that they were founded on love or justice. Ours is founded upon hatred. In our world there will be no emotions except fear, rage, triumph and self-abasement. Everything else we shall destroy - everything. Already we are breaking down the habits of thought which have survived from before the Revolution. We have cut the links between child and parent, and between man and man, and between man and woman. No one dares trust a wife or a child or a friend any longer. But in the future there will be no wives and no friends. Children will be taken from their mothers at birth, as one takes eggs from a hen. The sex instinct will be eradicated. Procreation will be an annual formality like the renewal of a ration card. We shall abolish the orgasm. Our neurologists are at work upon it now. There will be no loyalty, except loyalty towards the Party. There will be no love, except the love of Big Brother. (Orwell 279-280)
\end{abstract}

The Party as the only source of 'true' knowledge is aware of the mistakes of the old civilisations, therefore, they know that altering the reality and creating a new god will not be enough. For this reason, they aim to abolish the essence of humanity and to do that they educate the youth of their nation to be only loyal to the Party and be always aware of the traitors among them. By creating a sense of paranoia, the Party demolish the possibilities of the meaningful relationships that could occur within a society. In the novel, Orwell gives an example of such children with the Parsons family while on the surface, Parsons is a devout follower of the Party and Winston is very sure that Parsons "would never be vaporized" (64). Surprisingly when he finds himself in the Ministry of Love waiting to be killed, he sees that this so-called good thinker is among the Party criminals because in his sleep he said "Down with Big Brother!" and he is heard and given away to the patrols by his seven years old daughter and most importantly Parsons is very proud of her (245). This example proves the lack of the emotional bonds among the family members and Parsons being proud of his daughter demonstrates that the Party is successful in their attempts to destroy the feelings of loyalty and love for in the end the only loyalty this kind of people have is towards to the Party and as long as they love and be loyal to the Party, the personal relations do not matter. As it is mentioned before the sole reason of the torture is to convert the rebels into their loyal subjects and force them to love Big Brother and nothing else, hence the Party has to eradicate every other connection. As the last link of humanity, Orwell in the novel depicts the proles, since they are not a part of the Party, they are allowed to have these connections. However, ironically in the novel, they are depicted by the other characters as non-human. Since the party re-defined the meaning of humanity, the proles cannot be accepted as human beings by the Party members for the reason that according to them, being a person means being loyal to the teachings of the Party. In short, in order to be human, a person should worship to Big Brother. Since Orwell believed that socialism due to the greed of the people who have the power turned out to be a dystopia in here with these examples, he demonstrates that these people to protect their utopia are ready to erase the humanity of their society. In the Spanish civil war and the UK during the Second World War, he witnessed the desire of this kind of people to create a society which is ready to follow their every order and along with this; he saw how people became numb after the effects of these events. In the Modern period, many writers sought to portray the effects of the war and Orwell with the feelings paranoia and numbness that run society illustrates that the war demolishes the humanity of human beings.

In the novel, other than meaningful human relations language comes to the front as the last link of memory and humanity. The Inner Party members are aware of the fact there is a strong relationship among memory, critical thinking and language and in order to destroy this relation, they systemically erase the language. The erosion and the use of language are the most powerful weapons of the Party. Through the use of language, they re-shape the reality and through the erosion of language, they erase the memory because the memory is based on the capacity of reflecting an idea by using words to externalise that certain concept and in this case, if people are unable to express their thoughts through the use of language, that idea does not find a place in the external reality. The Newspeak, the new version of Standard English or Oldspeak as it is called in the novel, is created for one purpose, destroying the freedom of thought and re-shaping the personality of the individual by reducing the number of the words in the language (Schneider 3). As a linguist, in the novel, Syme 
states that "Even now, of course, there's no reason or excuse for committing thoughtcrime. It's merely a question of self-discipline, reality-control. But in the end there won't be any need even for that. The Revolution will be complete when the language is perfect." (Orwell 55), at the end of the novel there is an essay titled as 'The Principles of Newspeak' and in this essay, Orwell explains that Newspeak helps the Party by not only creating new words to express their ideology more effectively but also by eliminating the words that carry a heretical meaning. For that reason, one can stress that the Party exists through the use of language. Considering that the most unforgivable crime in Oceania is the thoughtcrime, the Party is afraid of the human beings' ability of critical thinking. For example, people like Winston are considered to be dangerous for they are able to remember and express themselves through language, even if it is performed in silence. Winston, since his job requires it, is able to use Newspeak effectively and this efficiency provides the possibility of comparing the Oldspeak and Newspeak. Newspeak allows him to understand how the Party controls its environment but since he is also a fluent speaker of Oldspeak, he does not understand why the Party is able to control them. The most important fact in this situation is that while Winston was born before the existence of the Party, the younger generation is born inside the language of the Party. Especially considering that Winston writes his diary in Oldspeak since he is only able to express his thoughts fully with it, it is not surprising that the younger generation is not even aware of this control. The language they use is the language of the Party; therefore, the Party is their existence and the only way they can express themselves verbally. As Syme says "Newspeak is Ingsoc and Ingsoc is Newspeak." (55). With these notions, Orwell demonstrates how much the external reality depends on the internal reality and the importance of language in the creation of reality, it can be stated that for this reason, the Modern writers chose to focus on describing the internal reality as it is the creator of the manner that one person perceives the notion of what is real and what is not.

Orwell believed that if only humans behave decently, the world would be a better place (Beadle 289), and wanted to warn the society about the possibility of a world that solely depends on the totalitarian understanding of the people who have power in their society and how this privileged class could abuse their power by benefiting from the powerless position of the lower classes. Regarding Nineteen Eighty-Four he claimed this:

\begin{abstract}
My recent novel is not intended as an attack on Socialism or on the British Labour party, (of which I am a supporter) but as a show-up of the perversions to which a centralised economy is liable and which have already been partly realized in Communism and Fascism. I do not believe that the kind of society I describe necessarily will arrive, but I believe ...that something resembling it could arrive. (qtd. in Beadle 297-298)
\end{abstract}

And for this reason, by some people the novel is considered to be a prophecy about the world after the Second World War. In general, the novel consists of 137 predictions about the near future (Goodman 33). Since the novel is a great example of dystopia, which is a sub-genre of sci-fi, these predictions within the novel are considered to be a warning about what could happen in the near future. Especially in the 21st century one can presume them to be true for today's London is no different Airstrip One's London, one of the most populated cities in Oceania. Today as it is described by Greg Diglin the city is "a spider web with cameras recording millions of citizens conducting their daily business" (37) and London in the novel is always watched by the Party members through the use of telescreens. Orwell was afraid of the fact that by reducing the numbers of words in the language, people were going to lose their ability of critical thinking and today the society, instead of Newspeak, uses the Netspeak and people are losing their capacities to use the standard version of their own language by practising Netspeak in daily life. Especially the younger generation is fluent in this new language and more importantly, they are unable to transform Netspeak into Standard English and vice versa (Diglin 614). Orwell's predictions about the near future are interesting because, in Nineteen Eighty-Four, he depicts a world which is controlled by the technological developments and today in a way our lives are controlled by the new media and this brings to the mind the question of 'Are we living in an Orwellian dystopia?' According to some critics, like Greg Diglin, Nineteen Eighty-Four is a sci-fi that depicts today and will depict the future. Along with this expression it should be noted that Orwell wrote Nineteen Eighty-Four with the inspiration he took from his own experiences during the war and he stated that the novel was a utopia ( qtd. in Enteen 206) Considering his ideas about the Fabians and 
socialists, Nineteen Eighty-Four was the utopia of a society that is always hungry for more power and the novel visualises the mentality of the modern people against this hungry world, as he says "War is the greatest of all agents of change. It speeds up all processes, wipes out minor distinctions, brings realities to the surface. Above all, war brings it home to the individual that he is not altogether an individual." (qtd. in Crothers 400) In the novel, one can observe that due to the consistent warfare people suffer from the loss of identity because the Party forces them to believe that they have to sacrifice their identities in order to establish a strong unity against evil forces which try to bring them down and to protect this so-called unity, the Inner Party members use technology effectively to eliminate the individuals who endanger their powerful position in the society.

To conclude, in Nineteen Eighty-Four, Orwell portrays the destructive effects of the abuse of power that happened during the Second World War and how it left a wounded society that is run by paranoia, fear and hatred. His involvement with BBC and the Ministry of Information during the war and his witnessing the one-track mindset of communists in the Spanish Civil War inspired him to create a universe that consistently feeds upon the propaganda of war to possess the control of the society. In the novel, with Ingsoc Party he explores the possibility of losing the war against the totalitarian people and while doing this, he explores the fragmented mind of the disillusioned modern society. As he said, Nineteen Eighty-Four depicts a utopia because the original aim of the three superpowers in the novel was to end the war, but because of the totalitarian mindset of the people who run society, Oceania was the dystopia of the ordinary modern people. With the manner he depicts his Oceania, in the novel, he portrays how the meaning of a utopia changes according to the individual's point of view. Especially the examples of O'Brien and Winston show this duality and the danger of a utopia becoming a dystopia. Orwell today remains as one of the rare writers whose name becomes an adjective which is 'Orwellian' and who added many words and notions to daily life like Big Brother, doublethink, thoughtcrime, Newspeak, Room 101, telescreen, $2+2=5$, and memory hole. Even only this achievement could prove the universality of the messages his novels consist of and how they are able to shape and describe the world.

\section{WORKS CITED}

Beadle, Gordon B. "George Orwell and the Victorian Radical Tradition." Albion: A Quarterly Journal Concerned with British Studies, Vol. 7, No. 4 (1975): 287-299.

Castresana, Carlos. "Torture as a Greater Evil." South Central Review, Vol. 24, No. 1, On Torture (2007): 119-130.

Crothers, Lane. "George Orwell And The Failure Of Democratic Socialism: The Political Power." Soundings: An Interdisciplinary Journal, Vol. 77, No. 3/4

Problem of 407

Diglin, Greg. "Living the Orwellian Nightmare: new media and digital dystopia." E-Learning and Digital Media Volume 11, Number 6 (2014): 608-618.

Enteen, George M. "George Orwell And The Theory Of Totalitarianism: A 1984 Retrospective." The Journal of General Education, Vol. 36, No. 3 (1984): 206-215.

Goodman, David A. "The 60th Anniversary of Orwell's 1984.” The New American. (2007): 33-38.

Greenblatt, Stephen. The Norton Anthology of English Literature, Eighth Edition, Volume 2. New York: W. W. Norton \& Company, Inc, 2006

Hammond, Andrew. "“The Twilight of Utopia': British Dystopian Fiction and the Cold War." The Modern Language Review 106.3 (2011): 662-681.

Hill, Patricia. "Religion and Myth in Orwell's 1984." Social Theory and Practice, Vol. 10, No. 3, A Special Issue: Orwell's 1984 (1984): 273-287.

Lamb, Peter. "Fabianism.” Encyclopcedia Britannica. Encyclopædia Britannica, Inc., 29 Nov. 2016. Web. 11 Apr. 2019.

Martin, Mike W. "Demystifying Doublethink: Self-Deception, Truth, and Freedom in 1984." Social Theory and Practice, Vol. 10, No. 3, A Special Issue: Orwell's 1984 (Fall 1984): 319-331. 
Orwell, George. 1984. London: Penguin Books, 2008.

Phillips, Lawrence. "Sex, Violence and Concrete: The Post-war Dystopian Vision of London in Nineteen Eighty-Four." Critical Survey 20.1 (2008): 69-79.

Roazen, Paul. "Orwell, Freud, And 1984." The Virginia Quarterly Review, Vol. 54, No.4 (1978): 675-695.

Schneider, Matthew. "A Paean to Power: Resistance to GA and Orwell's Nineteen Eighty-Four." Anthropoetics 16, no. 1 (2010): 1-8.

Sperber, Murray. “'Gazing Into The Glass Paperweight': The Structure and Psychology

of Orwell's '1984'.” Modern Fiction Studies, Vol. 26, No.2 (1980): 213- 226.

Taunton, Matthew. "British Modernism and the Idea of Russia." The British Library. The British Library, 27 Apr. 2016. Web. 11 Apr. 2019. 